\title{
Tingkat Perubahan Tutupan Lahan (Deforestasi) di DAS Tiworo Kabupaten Muna Barat
}

Taufik $^{1}$, Jamal Mukaddas ${ }^{1}$, Hasddin ${ }^{1^{*}}$

${ }^{1}$ Program Studi Perencanaan Wilayah dan Kota, Fakultas Teknik, Universitas Lakidende, Indonesia "Korespondensi: hasddinunilaki@gmail.com

\begin{tabular}{|c|c|}
\hline Info Artikel & \\
\hline $\begin{array}{c}\text { Diterima 19 April } \\
2021 \\
\text { Disetujui } 25 \text { Mei } \\
2021 \\
\text { Dipublikasikan } 27 \\
\text { Mei } 2021 \\
\text { Kata Kunci: } \\
\text { DAS Tiworo, } \\
\text { Tingkat Perubahan, } \\
\text { Deforestasi }\end{array}$ & $\begin{array}{l}\text { Tiworo dalam sepuluh (10) tahun yakni tutupan lahan } 2010,2015 \text { dan } \\
\text { 2020. Penelitian ini termasuk penelitian kualitatif dengan menggunakan } \\
\text { desain survei. Instrument yang digunakan adalah komputer PC/laptop, } \\
\text { software ArcGIS versi 10.4, GPS (global positioning sistem), peta DAS dan } \\
\text { peta administrasi, kamera, alat tulis serta foto citra landsat ETM+ dan citra } \\
\text { sentinel. Data dianalisis secara spasial (aplikasi GIS) dan deskriptif. Hasil } \\
\text { analisis diketahui bahwa DAS Tiworo dalam periode tahun } 2010-2020 \\
\text { mengalami deforestasi sekitar } 1.107,62 \text { ha atau sekitar } 110 \text { ha/tahun. } \\
\text { Deforestasi yang ditandai dengan penurunan luas terjadi pada hutan } \\
\text { sekunder dan hutan mangrove berubah menjadi kebun campuran, } \\
\text { pertanian lahan kering dan tambak. Akibat dari penurunan luasan } \\
\text { tersebut, maka berkonsekuensi pada peningkatan luas tutupan lahan } \\
\text { bukan hutan/bervegetasi yakni permukiman, pertanian lahan kering, dan } \\
\text { tambak. } \\
\text { Abstract } \\
\text { This study aimed to analyze changes in land cover (deforestation) in ten } \\
\text { (10) years, namely land cover Tiworo Watershed in } 2010,2015 \text { and } 2020 . \\
\text { This research is a qualitative research using a survey design. The } \\
\text { instruments used were PC/laptop computers, ArcGIS software version } \\
\text { 10.4, GPS (global positioning system), DAS maps and administrative } \\
\text { maps, cameras, stationery, ETM + Landsat images, and sentinel imagery. } \\
\text { Data were analyzed spatially (GIS application) and descriptively. The } \\
\text { results of the analysis show that the Tiworo watershed in the } 2010-2020 \\
\text { period experienced deforestation of around 1,107.62 ha or around } 110 \\
\text { ha/year. Deforestation which is marked by a decrease in area occurs in } \\
\text { secondary forests and mangrove forests that have turned into mixed } \\
\text { gardens, dry land farming and ponds. As a result of this reduction in area, } \\
\text { the consequence is an increase in non-forest/vegetated land cover areas, } \\
\text { namely settlements, dry land agriculture, and fish ponds. }\end{array}$ \\
\hline
\end{tabular}




\section{Pendahuluan}

Daerah aliran sungai (DAS) merupakan sumberdaya alam yang berfungsi sebagai stock atau modal alam (natural capital) yang didalamnya menghasilkan sumberdaya seperti kayu, rotan, air, mineral, ikan, dan lainnya yang diproduksi sebagai sumber ekonomi (Kartodihardjo, 2017). Hanya saja, pemanfaatan sumberdaya alam (DAS) kini mengalami tekanan akibat dari meningkatnya jumlah penduduk, pada saat yang bersamaan ketersediaan lahan cenderung tetap sehingga menyebabkan kerusakan DAS seperti illegal logging, alih fungsi lahan dan lainnya yang mengakibatkan lahan hutan mengalami deforestasi.

Deforestasi merupakan perubahan kondisi penutupan lahan dari hutan menjadi bukan hutan (termasuk perubahan untuk perkebunan, pemukiman, kawasan industri, dan lain-lain) (Kementerian LHK RI. 2016). Sementara Direktur Jendral Planologi (2015) menyebutkan bahwa deforestasi yaitu luas perubahan kondisi tutupan lahan dari kelas tutupan lahan kategori hutan/berhutan menjadi kelas tutupan lahan kategori non hutan/tidak berhutan. Reforestasi yaitu luas perubahan kondisi tutupan lahan dari kelas tutupan lahan kategori tidak berhutan menjadi kelas tutupan lahan kategori berhutan.

Penggunaan lahan (land use) diartikan sebagai setiap bentuk interaksi (campur tangan) manusia terhadap lahan dalam rangka memenuhi kebutuhan hidupnya baik material (Baja, S dkk.' 2009). Selanjutnya Arsyad (2010) menyebutkan bahwa penggunaan lahan sediri dibagi dua golongan besar yaitu penggunaan lahan pertanian dan penggunaan lahan bukan pertanian.

Perubahan penggunaan lahan dipengaruhi oleh dua faktor yaitu faktor alami (iklim, topografi, tanah atau bencana alam); dan faktor manusia berupa aktifitas manusia pada sebidang lahan (Widiatmaka, \& Soeka, 2012). Faktor manusia dirasakan berpengaruh lebih dominan dibandingkan dengan faktor alam karena sebagian besar perubahan penggunaan lahan disebabkan oleh aktifitas manusia dalam memenuhi kebutuhan lahan yang spesifik (Ardiansyah, dkk.' 2013), mendorong terjadinya penggunaan lahan yang tidak sesuai dengan peruntukannya, daerah persawahan berubah menjadi permukiman, sedangkan hutan sebagai kawasan perlindungan berubah menjadi lahan pertanian (Fatahillah, 2013).

Alih fungsi lahan di DAS telah menimbulkan masalah ekologi sebagai akibat dari pertumbuhan penduduk, kegiatan alih fungsi lahan tidak dapat dihindari sehingga berdampak langsung pada kondisi tutupan lahan DAS. Luas DAS Tiworo sekitar 32.636,48 ha, terdiri dari lahan berhutan seluas 5.703 ha, kebun campuran sekitar 6.700 ha, tegalan seluas 4.057,79 ha, dan sisanya adalah penggunaan lain (permukiman) (Hasddin, 2019). Luas lahan berhutan DAS Tiworo menurun sekitar $13,53 \%$, tegalan mengalami peningkatan luas secara signifikan hingga $35,56 \%$ (Hasddin, 2019). Dari data tersebut maka DAS Tiworo telah mengalami degradasi (perubahan tutupan lahan).

Hasddin (2019) menyebutkan bahwa dari akumulasi tingkatan erosi sudah sangat mengkhawatirkan yakni sebesar $57 \%$, dengan sedimen mencapai 334.130,69 ton/tahun. Pada kasus lain, DAS Citarum misalkan luas tutupan hutan hanya $15,96 \%$ dan hanya $4,94 \%$ luas hulu dari luas DAS. Akibatnya, terjadi erosi tahunan sebesar $933,03 \mathrm{~mm}$ dan 517,9 ton/ha. Penurunan luas tutupan hutan 
sebesar $10 \%$ dari kondisi existing menyebabkan $58 \%$ air hujan yang jatuh menjadi limpasan permukaan (Salim, dkk.' 2019).

Pengelolaan DAS Tiworo dimasa akan datang diperlukan data dasar gambaran secara spasial (keruangan) mengenai perubahan penggunaan lahan saat ini sehingga dapat melakukan upaya-upaya perlindungan DAS. Oleh sebab itu, untuk kepentingan kebutuhan data dan informasi perlu dilakukan monitoring perubahan tutupan lahan di DAS Tiworo.

Tujuan penelitian ini adalah menganalisis perubahan tutupan lahan (deforestasi) beserta sebaranya serta penyebab perubahan deforestasi dalam sepuluh (10) tahun. Analisis dibagi dalam 3 range waktu yakni tutupan lahan DAS Tiworo tahun 2010, 2015 dan 2020.

\section{Metode Penelitian}

Penelitian ini dilaksanakan di DAS Tiworo yang secara administratif berada di Kabupaten Muna Barat. Penelitian ini termasuk penelitian kualitatif dengan menggunakan desain survei untuk mendapatkan data dan informasi secara actual.

Alat yang digunakan dalam penelitian adalah komputer PC/laptop, software ArcGIS versi 10.4, GPS (global positioning sistem), peta DAS dan peta administrasi, kamera, alat tulis serta foto citra landsat ETM+ dan citra sentinel. Data dianalisis secara spasial (aplikasi GIS) dan deskriptif.

Tahapan analisis data diuraikan sebagai berikut:

1. Klasifikasi citra satelit

Klasifikasi menggunakan citra landsat ETM+ tahun 2004 dan 2011, citra sentinel tahun 2018. Proses ini dilakukan untuk memperoleh data penggunaan lahan dengan metode klasifikasi OBIA (Object Based Image Analisis) pada sofware SAGA. Kemudian perubahan penggunaan lahan dapat diketahui dari penggunaan lahan tiap tahun melalui proses overlay.

Pengklasifikasian mengacu pada Peraturan Direktur Jenderal Planologi Kehutanan Nomor: P.1/VII-IPSDHI/2015.

2. Survey lapangan (Ground check)

Survey lapangan dilakukan untuk mencocokkan hasil klasifikasi dengan kondisi yang sebenarnya dilapangan berdasarkan jumlah titik sampel masingmasing kelas penggunaan lahan. Dalam hal ini Ground check hanya dilakukan pada penggunaan lahan hasil klasifikasi citra sentinel tahun 2020.

3. Uji Akurasi, dilakukan dari hasil pencocokkan klasifikasi dengan hasil ground check, dengan menggunakan metode confussion matrix.

\section{Hasil dan Pembahasan}

\subsection{Hasil}

Doforestasi adalah perubahan penutupan lahan dari hujan menjadi bukan hutan (Kementerian LHK RI, 2016). Analisa sebaran doferestasi (perubahan tutupan lahan) di DAS Tiworo dimaksudkan untuk mengetahui dinamika perubahan tutupan lahan pada masing-masing kelas tutupan lahan. Obyek amatan 
perubahan tutupan lahan dilakukan dalan periode sepuluh (10) tahun yang dibagi dalam 3 (tiga) range data yakni periode tahun 2010, 2015 dan 2020.

Berdasarkan hasil interpretasi citra satelit landsat tahun 2010, 2015 dan 2020, diketahui bahwa terdapat 7 (tujuh) kelas penutupan lahan di DAS Tiworo yakni; hutan sekunder, kebun campuran, permukiman, pertanian lahan kering, mangrove, tambak dan tubuh air. Luas keseluruhan tutupan lahan DAS Tiworo adalah adalah $25.445,84$ ha. Luas dan sebaran perubahan DAS Ronta menurut kelas tutupan lahan selengkapnya disajikan pada Tabel 1.

Tabel 1. Punutupan Lahan DAS Tiworo Tahun 2010, 2015 dan 2020 (Sumber: Hasil Analisis, 2020)

\begin{tabular}{|c|c|c|c|c|c|c|c|}
\hline \multirow{2}{*}{ No } & \multirow{2}{*}{ Penutupan Lahan } & \multicolumn{3}{|c|}{ Luas (Ha) } & \multicolumn{3}{|c|}{ Persentase (\%) } \\
\hline & & 2010 & 2015 & 2020 & 2010 & 2015 & 2020 \\
\hline 1 & Hutan Sekunder** & $7.304,96$ & $6.665,96$ & $6.254,63$ & 28,71 & 26,20 & 24,58 \\
\hline 2 & Kebun Campuran** & $10.307,15$ & $9.724,51$ & $9.324,96$ & 40,51 & 38,22 & 36,65 \\
\hline 3 & Permukiman* & 705,85 & 813,35 & 941,77 & 2,77 & 3,20 & 3,70 \\
\hline 4 & Pertanian Lahan Kering* & $6.617,23$ & $7.731,36$ & $8.413,83$ & 26,01 & 30,38 & 33,07 \\
\hline 5 & Hutan Mangrove ${ }^{\star *}$ & 317,45 & 288,37 & 260,16 & 1,25 & 1,13 & 1,02 \\
\hline 6 & Tambak* & 157,58 & 186,66 & 214,87 & 0,62 & 0,73 & 0,84 \\
\hline 7 & Tubuh Air & 35,62 & 35,62 & 35,62 & 0,14 & 0,14 & 0,14 \\
\hline Tot & & $25.445,84$ & $25.445,84$ & $25.445,84$ & 100,00 & 100,00 & 100,00 \\
\hline
\end{tabular}

Keterangan: $\quad{ }^{* * K e l a s ~ L a h a n ~ y a n g ~ M e n g a l a m i ~ P e n u r u n a n ~ L u a s ~}$

*Kelas Lahan yang Mengalami Peningkatan Luas

Data-data diatas kemudian dilakukan uji perubahan tutupan lahan melalaui uji interpretasi data (keabsahan atau ketelitian) terhadap klasisfikasi citra landsat tahun 2020 data hasil survey lapangan (Ground Check). Uji data dilakukan untuk memperoleh tingkat ketelitian untuk mendapatkan derajat kebenaran data yang diperoleh melalaui interptetasi data. Hasil uji hasil interpretasi penutupan lahan DAS Tiworo tahun 2018 menurut Confussion Matrix selengkapnya disajikan pada Tabel 2.

Tabel 2. Confussion Matrix Hasil Klasifikasi Tutupan Lahan Tahun 2018 (Sumber: Hasil Analisis 2020

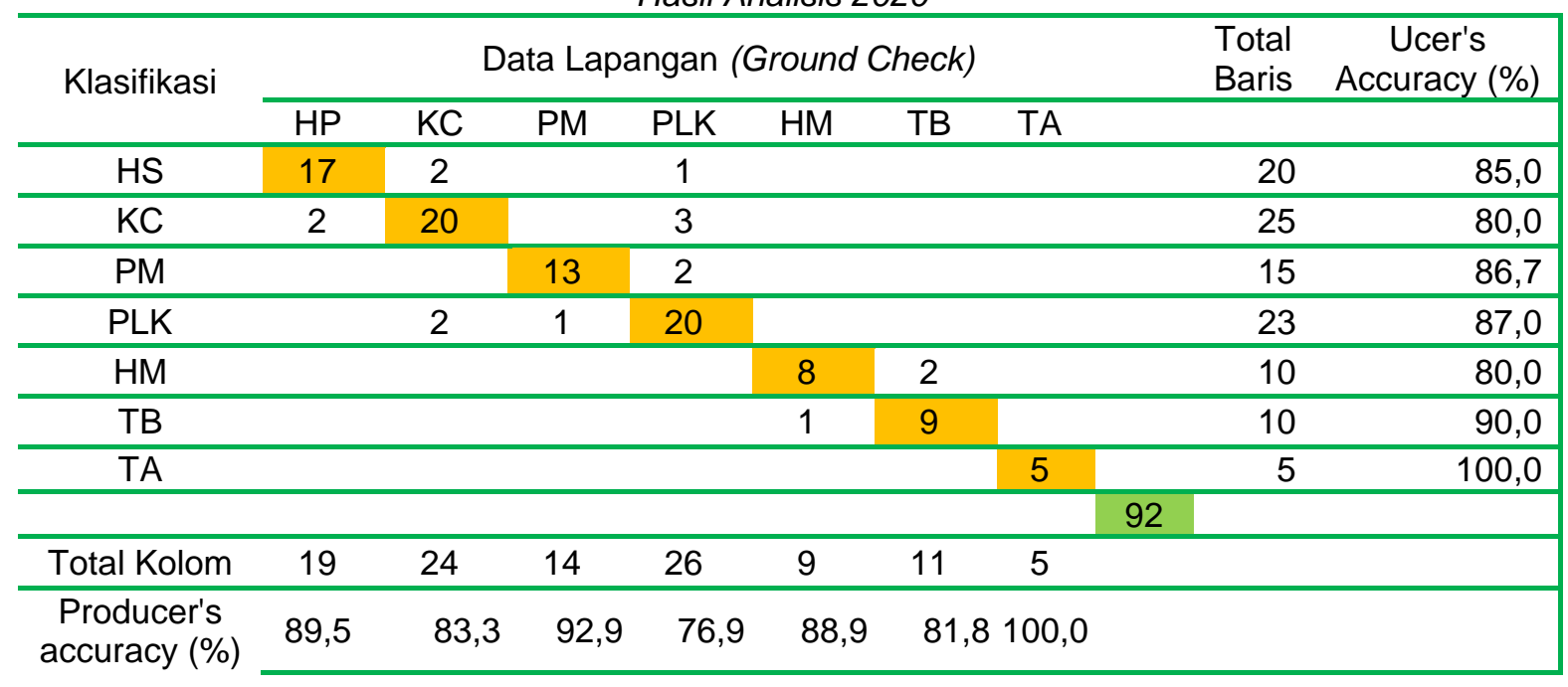




\begin{tabular}{|c|c|c|c|c|}
\hline \multirow{2}{*}{$\begin{array}{c}\text { Overall } \\
\text { accuracy } \\
\text { Keterangan : }\end{array}$} & \multicolumn{4}{|l|}{92,00} \\
\hline & (HS) & Hutan Sekunder & $(H M)$ & Hutan Mangrove \\
\hline & $(K C)$ & Kebun Campuran & $(T B)$ & Tambak \\
\hline & $(P M)$ & Pemukiman & $(T A)$ & Tubuh Air \\
\hline & $(P L K)$ & Pertanian Lahan Kering & & \\
\hline & & Titik yang Sesuai & & Jumlah Titik yang sesuai \\
\hline
\end{tabular}

Berdasarkan hasil uji interpretasi penutupan lahan DAS Tiworo tahun 2020 diatas diperolah bahwa tingkat kesesuaian dan akurasi data menurut confusion matrix sebesar $92,00 \%$. Hal ini berarti bahwa data dalam penelitian dianggap benar. Menurut Short (1982) dalam Nawangwulan dkk.'(2013) bahwa klasifikasi citra dianggap benar jika hasil perhitungan confusion matrix $\geq 80 \%$. Dengan demikian, data hasil interpretasi penutupan lahan DAS Tiworo tahun 2020 layak dijadikan dasar dalam mengeneralisasi data-data perubahan tutupan lahan.

Data perubahan tutupan lahan tahun 2010, 2015 dan tahun 2020 selengkapnya disajikan pada Gambar 1, 2 dan Gambar 3.

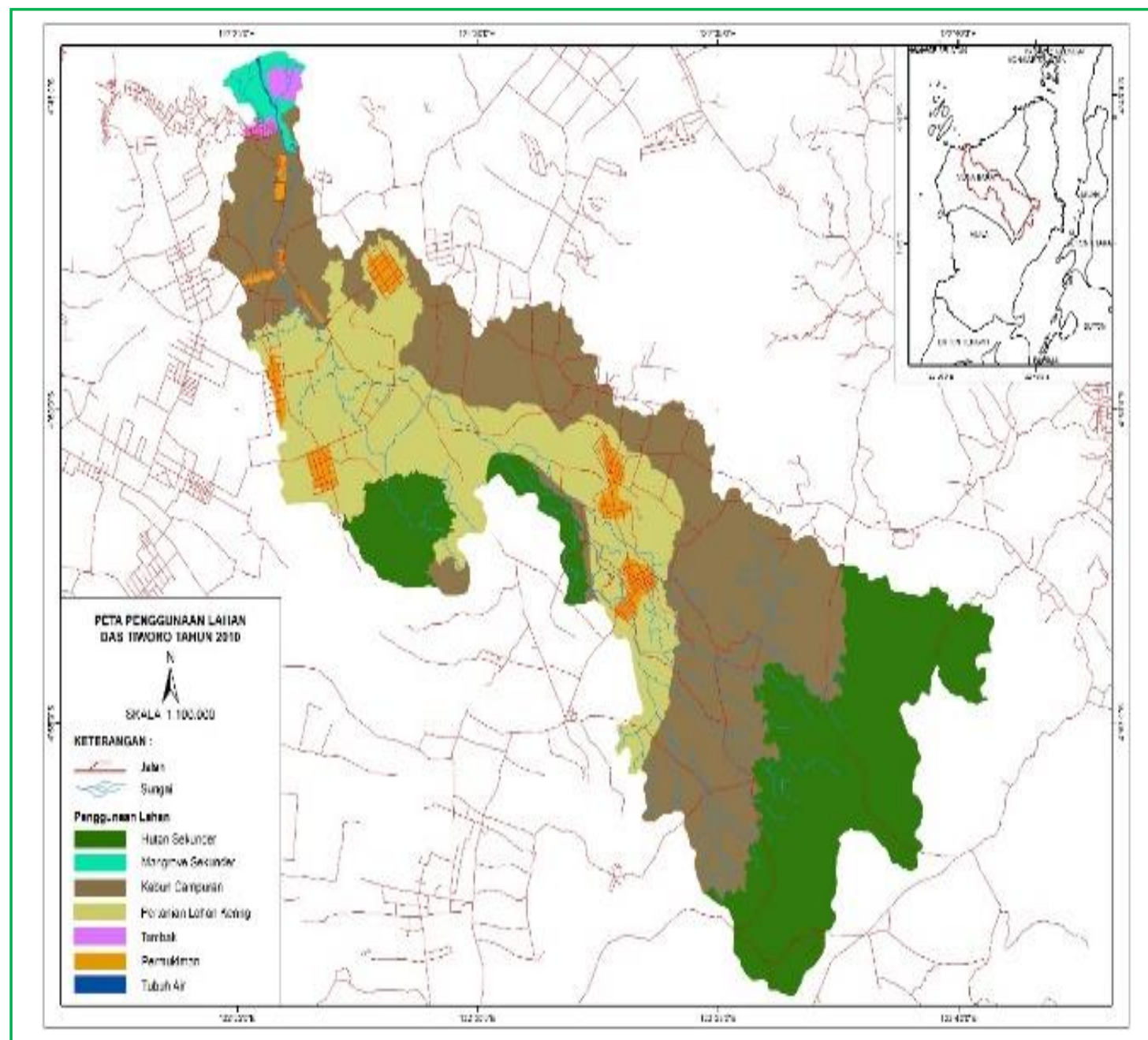

Gambar 1. Tutupan Lahan DAS Tiworo Tahun 2010 (Hasil Analisis, 2020) 


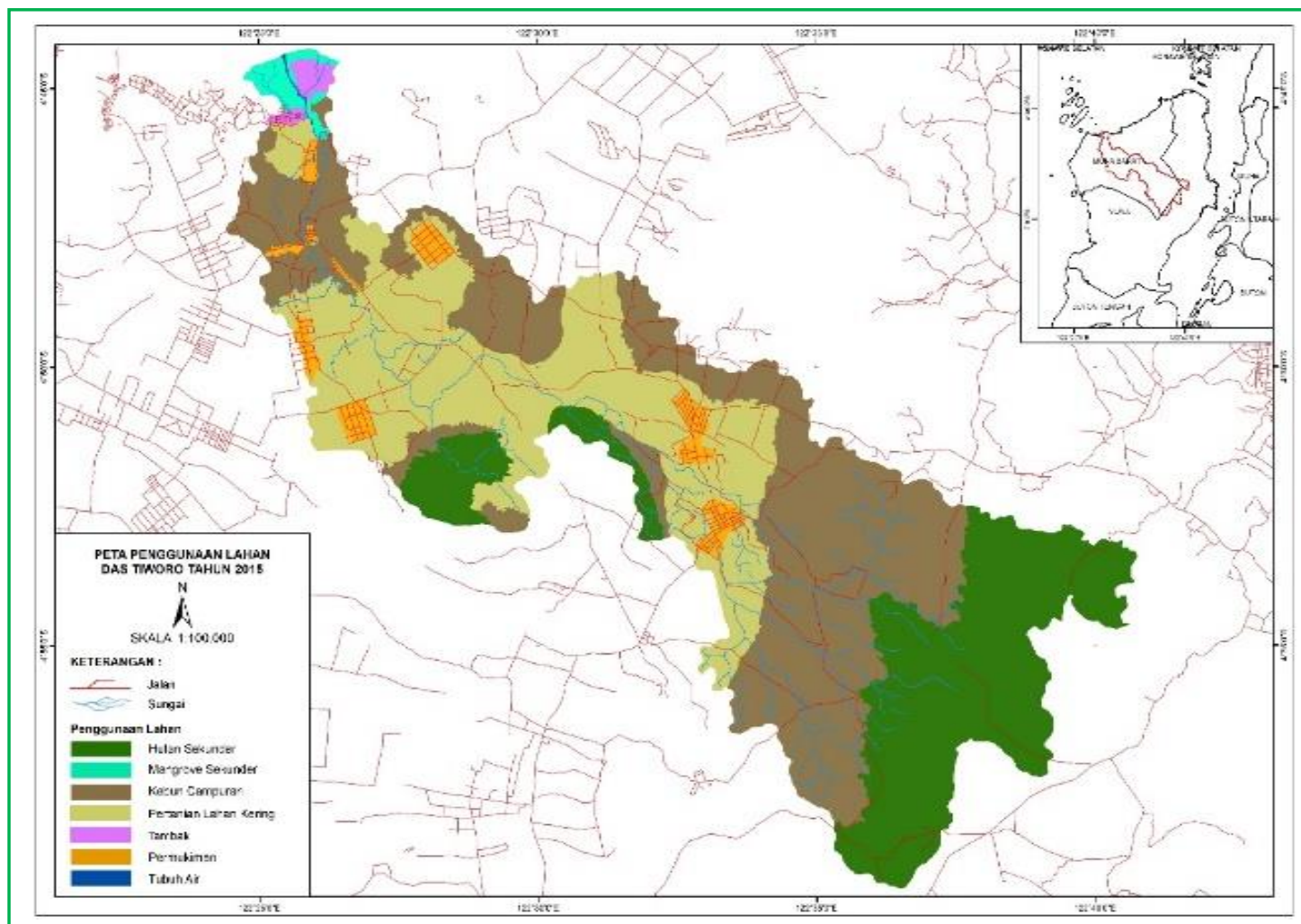

Gambar 2. Tutupan Lahan DAS Tiworo Tahun 2015 (Hasil Analisis, 2020)

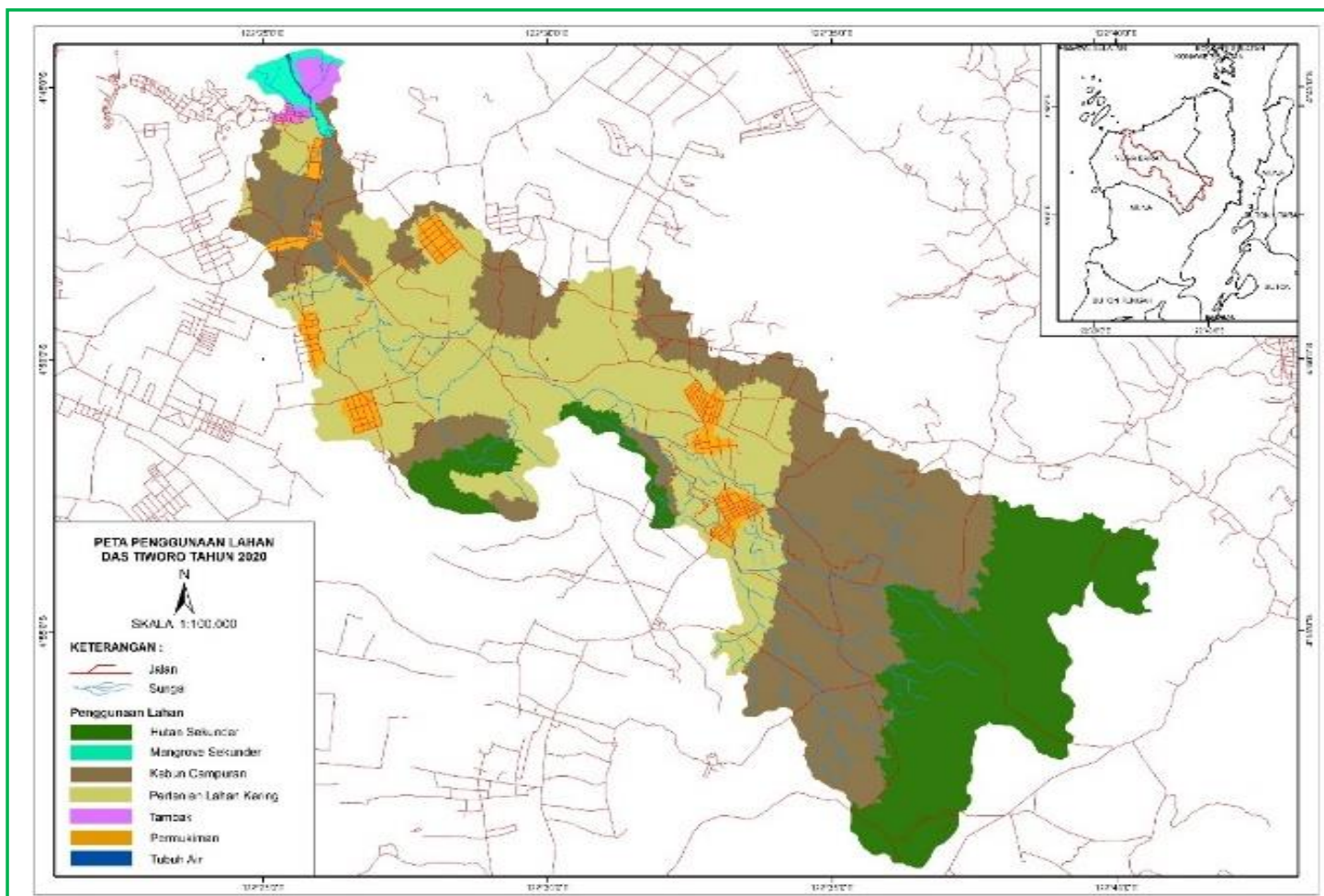

Gambar 3. Tutupan Lahan DAS Tiworo Tahun 2020 (Hasil Analisis, 2020) 
Berdasarkan hasil penelitian perubahan tutupan lahan di DAS Tiworo dalam kuurng waktu sepuluh (10) tahun tarakhir yakni 2010-2020 diketahui bahwa DAS Tiworo telah mengalami deforestasi. Luas lahan yang mengalami deforestaasi di DAS Tiworo disajikan pada Tabel 3.

Tabel 3. Luas Deforestasi di DAS Tiworo Tahun 2010-2020 (Sumber: Hasil Penelitian Diolah 2020)

\begin{tabular}{|c|c|c|c|c|c|}
\hline \multirow{2}{*}{ No } & \multirow{2}{*}{ Penutupan Lahan } & \multicolumn{2}{|c|}{ Luas (ha) } & \multirow{2}{*}{ Luas (ha) } & \multirow{2}{*}{ Luas (thn/ha) } \\
\hline & & 2010 & 2020 & & \\
\hline \multirow[t]{2}{*}{1} & Berhutan & $7.622,41$ & $6.514,79$ & $-1.107,62$ & \multirow{3}{*}{110} \\
\hline & $(\%)$ & 29,96 & 25,60 & & \\
\hline \multirow[t]{3}{*}{2} & Tidak Berhutan & $17.823,43$ & $18.931,05$ & $1.107,62$ & \\
\hline & $(\%)$ & 70,04 & 74,40 & & \\
\hline & DAS Tiworo & $25.445,84$ & $25.445,84$ & & \\
\hline
\end{tabular}

\subsection{Pembahasan}

Hasil analisis diketahui bahwa tutupan lahan yang dominan di DAS Tiworo adalah pada tiga jenis yakni hutan sekunder, kebun campuran dan pertanian lahan kering. Hal ini berarti bahwa selaian hutan, ada aktifitas pemanfaatan lahan lain di DAS Tiworo seperti kegiatan pertanian dan permukiman. Perubahan tutupan lahan yang ditandai dengan penurunan luas terjadi pada hutan sekunder, kebun campuran dan hutan mangrove. Data tersebut menunjukan bahwa dalam kurung waktu tahun 2010-2020 terjadi deforestasi di DAS Tiworo dari penutupan lahan berhutan (khususnya hutan sekunder dan mangrove) menjadi penutupan lain.

Akibat dari penurunan luasan tersebut, maka berkonsekuensi pada perubahan kelas tutupan lahan yang ditandai dengan penurunan luas bervegtasi (hutan) dan peningkatan luas tutupan lahan non vegetasi. Pada Tabel 1 diketahui bahwa kelas penutupan lahan DAS Tiworo yang mengalami penurunan pada periode waktu 2010-2020 adalah hutan sekunder dan hutan mangrove. Luas tutupan lahan hutan sekunder tahun 2010 adalah 7.304,96 ha turun menjadi $6.665,96$ ha ditahun 2015 dan turun menjadi $6.254,63$ ha ditahun 2020. Luas tutupan lahan mangrove tahun 2010 adalah 317,4 ha, tahun 2015 turun menjadi 288,37 ha dan tahun 2020 turun menjadi 260,16 ha. Luas tutupan lahan yang mengalami peningkatan luas adalah permukiman, pertanian lahan kering, dan tambak. Tahun 2010 luas tutupan lahan permukiman adalah 705,85 ha, tahun 2015 meningkat menjadi 813,35 ha dan tahun 2020 meningkat menjadi 941,77 ha. Luas tutupan lahan pertanian lahan kering tahun 2010 adalah 6.617,23 ha, tahun 2015 meningkat menjadi 7.731,36 ha dan tahun 2020 meningkat menjadi 8.413,83 ha. luas penutupan lahan untuk tambak tahun 2010 adalah 157,58 ha, tahun 2015 meningkat menjadi 186,66 ha dan tahun 2020 meningkat menjadi 214,87 ha.

Data Tabel 3 diketahui bahwa luas deforetasi yang terjadi di DAS Tiworo selama kurung waktu 2010-2020 adalah 1.107,62 ha atau sekitar 110 ha/tahun. Penurunan luas hutan (deforestasi) sejalan dengan penelitian Hasddin (2019a) dan Hasddin (2019b) bahwa selama tahun 2009-2014 terjadi penurunan luas hutan sebesar 772 ha atau sekitar128,67 ha/tahun atau mengalami deforestasi sebesar $13,53 \%$. 
Dengan adanya aktifitas pemanfaatan (permukiman dan kegiatan pertanian) dalam suatu kawasan hutan (termasuk DAS), akan berdampak terhadap aktivitas pemanfaatan lahan lain yang berimplikasi pada perubahan tutupan lahan. Dengan adanya pusat kegiatan dalam kawasan akan sangat memudahkan (terutama faktor jarak) dalam melakukan aktifitas pemanfaatan dalam kawasan hutan. Ahmad et al.' (2016) dalam menelitianya menyatakan bahwa perubahan tutupan lahan (deforestrasi) sangat terkait dengan aktifitas pemukiman sebagai akibat dari pertumbuhan dan kepadatan penduduk.

Dari hasil monitoring perubahan tutupan lahan DAS Tiworo tahun 2010, 2015 dan 2020 dapat diketahui penyebab deforestasi. Penyebab pertama adalah adanya aktifitas bertambahnya luas permukiman sebagai akibat dari pertumbuhan jumlah penduduk. Ini terlihat dari luas tutupan lahan tahun 2010 seluas 705,85 ha, meningkat menjadi 813,35 ha ditahun 2015 dan menjadi 941,77 ha ditahun 2020. Artinya bahwa selama periode tahun 2010-2020, permukiman mengalami peningkatan luas sekitar 235,92 ha atau sekitar 29,24\%. Peningkatan luas permukiman di DAS Tiworo berkorelasi (berbanding lurus) dengan peningkatan jumlah penduduk Muna Barat. Dari data BPS diketahui bahwa jumlah penduduk Muna Barat Tahun 2015 sebanyak 77.084 jiwa (BPS Muna Barat, 2016) dan mengalami peningkatan ditahun 2020 dengan total jumlah penduduk sebanyak 83.100 jiwa (BPS Muna Barat, 2019).

Penyebab kedua adalah konversi lahan hutan menjadi pertanian lahan kering dan kebun campuran. Pada periode tahun 2010-2015, luas tutupan lahan hutan sekunder berkurang dan berubah menjadi kebun campuran seluas 599,23 ha dan pada periode tahun $2015-2020$ seluas 310,26 ha. Tutupan lahan hutan sekunder juga dikonversi menjadi pertanian lahan kering seluas 39,77 ha pada periode tahun 2010-2015 dan 101,08 ha pada periode tahun 2015-2020. Penyebab ketiga adalah perambahan hutan mangrove dan dikonversi menjadi tambak. Luas lahan mangrove yang dikonversi menjadi tambak adalah 29,09 ha pada periode tahun 2010-2015 dan 28,21 ha diperiode tahun 2015-2020.

Penyebab deforestasi DAS Tiworo juga ditemukan pada DAS lain sebagaimana hasil penelitian Mawardi (2010) bahwa alih fungsi lahan di DAS telah menimbulkan masalah ekologi sebagai akibat dari pertumbuhan penduduk, kegiatan alih fungsi lahan tidak dapat dihindari sehingga berdampak langsung pada kondisi tutupan lahan DAS. Selanjutnya Salim dkk, (2019) dalam penelitianya menyebutkan bahwa DAS Citarum Hulu telah mengalami penurunan luas tutupan hutan sebesar $10 \%$ sebagai akibat dari alih fungi lahan menjadi non hutan (permukiman dan lainnya).

\section{Kesimpulan}

Kurung waktu tahun 2010-2020, DAS Tiworo telah mengalami deforestasi sekitar 1.107,62 ha atau 110 ha/tahun. Deforestasi terjadi akibat pemanfaatan lahan berupa kebun campran dan pertanian lahan kering. Hutan mangrove mengalami deforestasi sebagai akibat dari kegiatan (konversi) menjadi tambak.

Sesui dengan simpulan tersebut, maka Pemerintah Kabupaten Muna Barat dan Badan Pengelolaan DAS Sulawesi Tenggara (BP-DAS Sampara) perlu merumuskan langkah bersama dalam pengendalian perubahan tutupan lahan di DAS Tiworo. Perlu ada kajian lanjutan untuk memprediksi perubahan tutupan 
lahan dimasa akan datang sesuai dengan kebijakan tata ruang serta pengaruhnya terhadap kondisi hidrologi dan sosial ekonomi.

\section{Ucapan Terima Kasih}

Ucapan terimakasih disampaiakan kepada Pemerintah Kabupaten Muna Barat dan BPDASHIL Sampara yang telah mengizinkan pelaksanaan penelitian dan data-data sekunder yang relavan dengan penelitian ini. Ucapan terima kasih juga disampaikan kepada Rektro Universitas Lakidende yang memberikan dorongan dan dukungan selama kegiatan penelitian.

\section{Daftar Pustaka}

Ahmad, A., Saleh, M. B., \& Teddy, R. (2016). Model Spasial Deforestasi Di KPHP Poigar, Provinsi Sulawesi Utara, Jurnal Penelitian Kehutanan Wallacea, 5(2), 159-169.

Ardiansyah, T., Lubis, K. S., \& Hanum, H. (2013). Kajian Tingkat Bahaya Erosi di Beberapa Penggunaan Lahan di Kawasan Hilir DAS Padang. Jurnal Online Agroekoteknologi ISSN, 2, 436-446.

Arsyad. (2010). Konservasi Tanah dan Air. Edisi Kedua, Bogor: IPB Press.

Badan Pusat Statistik (BPS) Kabupaten Muna Barat. (2016). Kabupaten Muna Barat dalam Angka 2016. Laworo: BPS Kabupaten Muna Barat.

Badan Pusat Statistik (BPS) Kabupaten Muna Barat. (2019). Kabupaten Muna Barat dalam Angka 2019. Laworo: BPS Kabupaten Muna Barat.

Baja, S., Ramli, M., \& Lias, S. A. (2009). Spatial-Based Assessment of Land Use, Soil Erosion, and Water Protection in the Jeneberang Valley, Indonesia. International Journal of Biologia, 64(3), 522-526.

Direktur Jendral Planologi, Kementerian Kehutanan. (2015). Deforestasi Indonesia Periode 2013-2014. Jakarta: Direktorat Inventarisasi dan Pemantauan Sember daya Hutan. Jakarta: Kementrial LHK.

Fatahillah. (2013). Kajian Keterpaduan Pengelolaan Daerah Aliran Sungai (DAS) Garang Provinsi Jawa Tengah. Jurnal Geografi, 10(2), 136-153.

Hasddin. (2019a). Karakteristik Sumberdaya Alam dan Rencana Pengelolaan DAS Tiworo Kabupaten Muna Barat. Jurnal Aksara Public, 3(2), 149-159.

Hasddin. (2019b). Valuasi Ekonomi Sumberdaya Alam Pada DAS Tiworo Kabupaten Muna Barat. Jurnal Akrab Juara, 4(2), 115-125.

Kartodihardjo, H. (2017). Dibalik Krisis Ekosistem: Kumpulan Percikan Pemikiran Seputar Kehutanan dan Lingkungan Hidup: Jakarta.

Kementerian LHK RI. (2016). Statistik Kementerian Lingkungan Hidup dan Kehutanan. Jakarta: Kementerian LHK.

Mawardi, I. (2010). Kerusakan Daerah Aliran Sungai dan Penurunan Daya Dukung Sumberdaya Air Di Pulau Jawa Serta Upaya Penanganannya. Jurnal Hidrosfir Indonesia, 5(2), 1-11. 
Nawangwulan, N. Hapsari., Sudarsono, Bambang dan Sasmito, Bandi. (2013). Analisis Pengaruh Perubahan Lahan Pertanian Terhadap Hasil Produksi Tanaman Pangan Di Kabupaten Pati Tahun 2001 - 2011. Jurnal Geodesi Undip 2(2), 127-140.

Salim, A.G., Dharmawan IWS., \& Narendra BH. 2019. Pengaruh Perubahan Luas Tutupan Lahan Hutan Terhadap Karakteristik Hidrologi DAS Citarum Hulu. Jurnal IImu Lingkungan, 17(2), 333-340.

Widiatmaka \& Soeka, B. D. G. (2012). Distribusi Spasial Besaran Erosi Untuk Perencanaan Peggunaan Lahan Lestari: Studi Kasus Unit Pemukiman Transmigrasi (UPT) Rantau Pandan SP-1, Provinsi Jambi. Jurnal Globe, 14(1), 60-69. 